\title{
Production of (R)-3-Quinuclidinol by $E$. coli Biocatalysts Possessing NADH-Dependent 3-Quinuclidinone Reductase (QNR or bacC) from Microbacterium luteolum and Leifsonia Alcohol Dehydrogenase (LSADH)
}

\author{
Kentaro Isotani, Junji Kurokawa and Nobuya Itoh * \\ Department of Biotechnology, Faculty of Engineering, Biotechnology Research Center, \\ Toyama Prefectural University, 5180 Kurokawa, Imizu, Toyama 939-0398, Japan; \\ E-Mails: s976001@st.pu-toyama.ac.jp (K.I.); z16072@st.pu-toyama.ac.jp (J.K.) \\ * Author to whom correspondence should be addressed; E-Mail: nbito@pu-toyama.ac.jp; \\ Tel.: +81-766-56-7500 (ext. 560); Fax: +81-766-56-2498.
}

Received: 30 August 2012; in revised form: 27 September 2012 / Accepted: 11 October 2012 / Published: 19 October 2012

\begin{abstract}
We found two NADH-dependent reductases (QNR and bacC) in Microbacterium luteolum JCM 9174 (M. luteolum JCM 9174) that can reduce 3-quinuclidinone to optically pure $(R)-(-)$-3-quinuclidinol. Alcohol dehydrogenase from Leifsonia sp. (LSADH) was combined with these reductases to regenerate $\mathrm{NAD}^{+}$to $\mathrm{NADH}$ in situ in the presence of 2-propanol as a hydrogen donor. The reductase and LSADH genes were efficiently expressed in E. coli cells. A number of constructed $E$. coli biocatalysts (intact or immobilized) were applied to the resting cell reaction and optimized. Under the optimized conditions, $(R)-(-)-3$-quinuclidinol was synthesized from 3-quinuclidinone $(15 \% \mathrm{w} / \mathrm{v}, 939 \mathrm{mM})$ giving a conversion yield of $100 \%$ for immobilized QNR. The optical purity of the $(R)-(-)$-3-quinuclidinol produced by the enzymatic reactions was $>99.9 \%$. Thus, $E$. coli biocatalysis should be useful for the practical production of the pharmaceutically important intermediate, $(R)-(-)$-3-quinuclidinol.
\end{abstract}

Keywords: 3-quinuclidinone reductase (QNR and bacC); Microbacterium luteolum JCM 9174; Leifsonia alcohol dehydrogenase (LSADH); (R)-(-)-3-quinuclidinol; optically pure alcohol; immobilized biocatalyst 


\section{Introduction}

The chemical processes for obtaining optically pure compounds include enantiomer separation from a racemic mixture, derivation from natural substances and asymmetric synthesis. Of these, asymmetric organic synthesis is the most efficient and useful method of producing chiral synthons. Chiral metal catalysts such as BINAP-Ru [1] and chiral Co (II) salen complex [2,3] have been successfully used as chemical catalysts for synthesizing chiral alcohols or chiral diols from various ketones or epoxides in a number of cases. However, trace metal contamination left in the products and the high cost of catalysts are unresolved difficulties affecting many reactions. To overcome the issues of conventional processes, biocatalytic transformation using enzymes or microorganisms has been applied to the asymmetric reduction of ketones. These biocatalytic processes are more environmentally sustainable and thus more attractive for pharmaceutical manufacturing [4]. In recent years, the asymmetric reduction of ketones with biocatalysts has been reported for the production of chiral alcohols and applied to industry [5-9].

$(R)-(-)-3-Q u i n u c l i d i n o l$, which has a bicyclic structure with a bridgehead nitrogen, is a valuable intermediate for pharmaceuticals. It has been used as the chiral synthon for a cognition enhancer, a bronchodilator and a urinary incontinence agent [10]. The optical resolution of ( \pm )-3-quinuclidinol esters by the hydrolysis reaction of protease has been reported [11]. Moreover, a number of enzymes have been reported as catalysts for the reduction of 3-quinuclidinone to $(R)-(-)$-3-quinuclidinol [12-14]. To accelerate the bioreduction process, it is necessary to regenerate $\mathrm{NAD}(\mathrm{P})^{+}$to $\mathrm{NAD}(\mathrm{P}) \mathrm{H}$ in situ . There have been many reports on the reproduction of $\mathrm{NAD}(\mathrm{P}) \mathrm{H}$ via coupling reactions using formate/formate dehydrogenase (FDH) [15] and glucose/glucose dehydrogenase (GDH) [16]. In the regeneration of $\mathrm{NAD}(\mathrm{P}) \mathrm{H}, 2$ 2-propanol is another suitable hydrogen donor because of its chemical properties and low cost $[17,18]$. Recently, our research group reported an excellent alcohol dehydrogenase from Leifsonia sp. strain S749 (LSADH) for the synthesis of chiral alcohols and concomitant regeneration of NADH with 2-propanol [19-21]. Biocatalytic reaction using whole cells is more stable than isolated enzyme reaction, and can reduce the cost of catalysts and cofactors [21,22].

Figure 1. $(R)-(-)-3-Q u i n u c l i d i n o l$ production system with 3-quinuclidinone reductase (QNR) and Leifsonia alcohol dehydrogenase (LSADH).

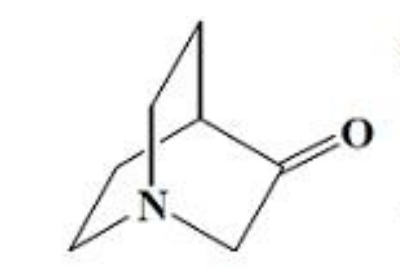

3-Quinuclidinone

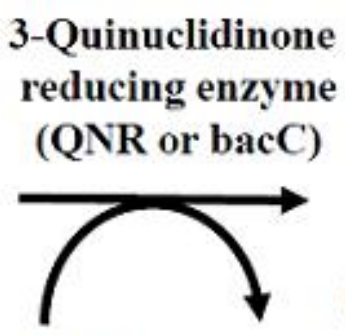

NADH NAD ${ }^{+}$

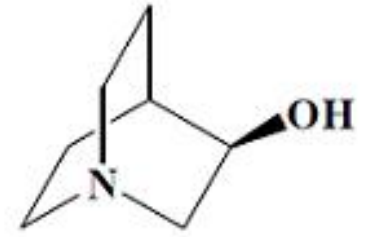

(R)-3-Quinuclidinol

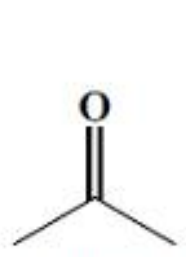

Acetone

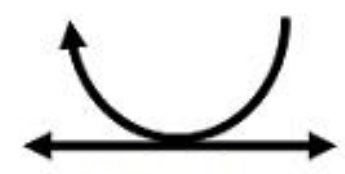

Alcohol dehydrogenase (LSADH)<smiles>CC(C)O</smiles>

2-Propanol 
In this study, we report a bioreduction system for synthesizing $(R)-(-)$-3-quinuclidinol using a recombinant $E$. coli cell biocatalyst possessing 3-quinuclidinone reductase (QNR or bacC) from M. luteolum JCM 9174 and LSADH (Figure 1). The bacC gene, which consists of 768 nucleotides corresponding to 255 amino acid residues and is a constituent of the bacilysin synthetic gene cluster, was obtained by PCR based on homology with known genes [23]. The qnr gene consisted of 759 nucleotides corresponding to 252 amino acid residues [24]. Both enzymes belong to the short-chain alcohol dehydrogenase/reductase (SDR) family. QNR showed 37\% homology with the bacC isolated from $M$. luteolum. The resulting $E$. coli biocatalyst exhibited a high level of production of $(R)-(-)$-3-quinuclidinol and enantioselectivity $(150 \mathrm{mg} / \mathrm{mL},>99.9 \%$ e.e. $)$.

\section{Results and Discussion}

\subsection{Construction of Expression Vector of QNR and LSADH}

pET28a (Merck KGaA, Darmstadt, Germany) and pRSFDuet-1 (Merck) vectors have the kanamycin resistance gene. Therefore, it was not suitable to select the colony having both plasmids. Thus, the qnr gene was subcloned into NdeI-HindIII sites of pETDuet-1, which has an ampicillin resistance gene, from pET28-QNR [24] to give pETDuet-QNR. The $l s a d h$ gene was amplified by PCR with the following primers and using pKELA [20] as a template: LSADHforNde (5'-GAGATCATATGGCTCAGTACGACGTC-3') (the NdeI site is underlined) and LSADHrevSal (5'-TTTGTCGACTCACTGGGCGGTGTAG-3') (the SalI site is underlined) under the following conditions: $94{ }^{\circ} \mathrm{C}$ for $2 \mathrm{~min}$, followed by $98{ }^{\circ} \mathrm{C}$ for $10 \mathrm{~s}, 60{ }^{\circ} \mathrm{C}$ for $30 \mathrm{~s}$ and $68{ }^{\circ} \mathrm{C}$ for $1 \mathrm{~min}$ for a total of 30 cycles in accordance with the manufacturer's protocol for KOD FX DNA polymerase (Toyobo, Osaka, Japan). The PCR fragments were digested with NdeI and SalI and inserted into NdeI and XhoI sites of pRSFDuet-1 (Merck) to obtain pRSFDuet-LSADH. For the co-expression of the $q n r$ and $l s a d h$, E. coli BL21 (DE3) was transformed with pETDuet-QNR and pRSFDuet-LSADH. Unfortunately, we could not construct pETDuet-QNR-LSADH.

\subsection{Construction of Expression Vector of bacC and LSADH}

The PCR fragment of $l s a d h$ mentioned above was digested with NdeI and SalI, and then cloned into the NdeI and XhoI sites of pETDuet-1 to obtain pETDuet-LSADH. Then, to add the T7 promoter region into the upstream of the $l s a d h$ gene, the fragment was amplified again by PCR with the pETDuet-LSADH as a template and the following primers: pETUpstream-69214-3 (5'-ATGCGTCCGGCGTAGA-3') and LSADHrevSal. The amplicon was digested with HindIII and SalI, and cloned into HindIII and XhoI sites of the pET28-bacC [23] to generate pET28-bacC-LSADH, in which the $b a c C$ and $l s a d h$ genes were connected in this order and each gene was under the control of the $\mathrm{T} 7$ promoter (Figure 2). 
Figure 2. pET28-bacC-LSADH plasmid.

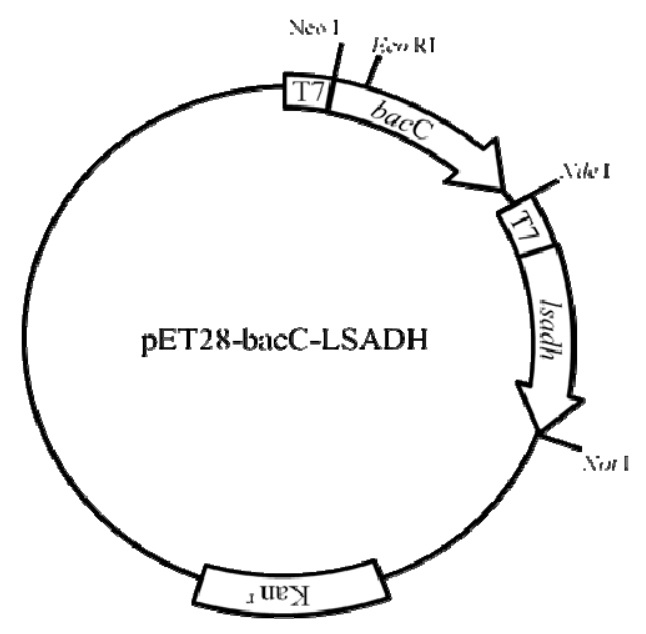

\subsection{Enzymatic Activity of the E. coli Biocatalyst}

Table 1 shows the results of the enzymatic activity of each $E$. coli biocatalyst. The activities of E. coli BL21(DE3)/pET28-QNR, E. coli BL21(DE3)/pET28-bacC and E. coli BL21/pKELA, in which the gene was independently expressed, indicated higher 3-quinuclidinone-reducing/2-propanol oxidizing activity than E. coli BL21 (DE3)/pETDuet-QNR/pRSFDuet-LSADH and E. coli BL21 (DE3)/pET28-bacC-LSADH, in which the two genes were co-expressed. The results suggested that the combination of two E. coli biocatalysts, for example, E. coli BL21(DE3)/pET28-QNR and E. coli BL21/pKELA, should be suitable for the conversion of 3-quinuclidinone.

Table 1. Enzyme activity of recombinant E. coli biocatalyst.

\begin{tabular}{ccc}
\hline Plasmid for expression & $\begin{array}{c}\text { 3-Quinuclidionone reduction } \\
\text { (U/mL culture broth) }\end{array}$ & $\begin{array}{c}\text { 2-Propanol oxidation } \\
\text { (U/mL culture broth) }\end{array}$ \\
\hline pET28-QNR * & 8.4 & 0 \\
pET28-bacC * & 0.3 & 0 \\
pETDuet-QNR/pRSFDuet-LSADH & 0.3 & 0.12 \\
pET28-bacC-LSADH & 0.1 & 0.09 \\
pKELA & 0 & 1.0 \\
\hline
\end{tabular}

* The specific activity of QNR was $12.2 \mathrm{U} / \mathrm{mg}$ protein, and that of bacC was $0.9 \mathrm{U} / \mathrm{mg}$ protein.

Moreover, in order to increase the durability of the biocatalyst, we immobilized the recombinant E. coli cells including E. coli BL21(DE3)/pET28-QNR, E. coli BL21(DE3)/pET28-bacC and E. coli BL21/pKELA by coating the cell surface with polyethyleneimine (PI) and glutaraldehyde (GA) [25]. Unfortunately, the activity of immobilized biocatalyst was not determined because the enzyme could not be extracted from the immobilized cells.

\subsection{Evaluation of E. coli Biocatalyst and Optimization of the Reaction}

Based on the enzyme activity shown in Table 1, we applied various combinations of biocatalysts to $(R)-(-)$-3-quinuclidinol synthesis. Table 2 summarizes the production level of $(R)-(-)$-3-quinuclidinol 
and the molar conversion yield. In all cases, the absolute configuration of $(R)-(-)-3$-quinuclidinol produced was $>99.9 \%$. Conversions of almost $100 \%$ were attained except for the combination of E. coli/pET28-bacC and E. coli/pKELA (ratio: 1:4), when the final 10\% (w/v, $626 \mathrm{mM}$ ) of 3 -quinuclidinone was employed in the reaction mixture. Low production was due to the insufficient 3-quinuclidinone-reducing activity of this combination of biocatalysts. Neither QNR nor bacC catalyzes the reverse reaction, $(R)-(-)$-3-quinuclidinol oxidation to 3-quinuclidinon [23,24]; therefore, the unfavorable equilibrium between alcohol and ketone was negligible. However, it was noted that the conversion yield decreased when $15 \%(w / v, 939 \mathrm{mM}) 3$-quinuclidinone was employed in the reaction mixture, even if twice the amount of biocatalyst was added. During the course of the study, we observed that more than $5 \%$ of 3 -quinuclidinone in the reaction mixture seemed to inhibit the reaction rate, suggesting that a high concentration of 3-quinuclidinone has an inhibitory effect on the enzyme catalysts. Thus, we adopted a method of consecutive additions of 3 -quinuclidinone $(5 \% \mathrm{w} / \mathrm{v})$ and 2-propanol $(5 \% v / v)$ to the reaction mixture at $8 \mathrm{~h}$ intervals. Under the optimized conditions, combinations of $E$. coli/pET28-QNR and $E$. coli/pKELA (4:1), E. coli/pET28-QNR and E. coli/pKELA $(1: 1)$ and $E$. coli/pETDuet-QNR/pRSFDuet-LSADH biocatalysts gave complete conversions of $10 \%$ 3-quinuclidinone to $(R)-(-)$-3-quinuclidinol.

Table 2. Production of $(R)-(-)-3$-quinuclidinol by various combinations of biocatalysts.

\begin{tabular}{|c|c|c|c|c|}
\hline & Biocatalyst & Amount of cells ${ }^{a}$ & $\begin{array}{c}\text { Cells-mixing } \\
\text { ratio } \\
\end{array}$ & $\begin{array}{l}\text { Production level }{ }^{\mathrm{b}} \text {, } \\
\text { molar conversion }\end{array}$ \\
\hline & Resting cells & & & \\
\hline \multirow[t]{5}{*}{ (a) } & pET28-QNR, pKELA & $40.6 \mathrm{mg}$ & $4: 1$ & $100 \mathrm{mg} / \mathrm{mL} \pm 1,100 \%$ \\
\hline & & $42.3 \mathrm{mg}$ & $1: 1$ & $100 \mathrm{mg} / \mathrm{mL} \pm 1,100 \%$ \\
\hline & & $43.9 \mathrm{mg}$ & $1: 4$ & $96 \mathrm{mg} / \mathrm{mL} \pm 2,96 \%$ \\
\hline & & $42.3 \mathrm{mg}$ & $1: 1$ & $51 \mathrm{mg} / \mathrm{mL} \pm 3,34 \%^{\mathrm{c}}$ \\
\hline & & $84.5 \mathrm{mg}$ & $1: 1$ & $63 \mathrm{mg} / \mathrm{mL} \pm 3,42 \%^{\mathrm{c}}$ \\
\hline \multirow[t]{5}{*}{ (b) } & pET28-bacC, pKELA & $40.2 \mathrm{mg}$ & $4: 1$ & $98 \mathrm{mg} / \mathrm{mL} \pm 2,98 \%$ \\
\hline & & $42.0 \mathrm{mg}$ & $1: 1$ & $99 \mathrm{mg} / \mathrm{mL} \pm 1,99 \%$ \\
\hline & & $43.8 \mathrm{mg}$ & $1: 4$ & $65 \mathrm{mg} / \mathrm{mL} \pm 3,65 \%$ \\
\hline & & $42.0 \mathrm{mg}$ & $1: 1$ & $34 \mathrm{mg} / \mathrm{mL} \pm 3,22 \%^{\mathrm{c}}$ \\
\hline & & $84.0 \mathrm{mg}$ & $1: 1$ & $58 \mathrm{mg} / \mathrm{mL} \pm 4,39 \%^{\mathrm{c}}$ \\
\hline (c) & pETDuet-QNR/pRSFDuet-LSADH & $35.5 \mathrm{mg}$ & - & $100 \mathrm{mg} / \mathrm{mL} \pm 1,100 \%$ \\
\hline \multirow[t]{2}{*}{ (d) } & pET28-bacC-LSADH & $36.5 \mathrm{mg}$ & - & $98 \mathrm{mg} / \mathrm{mL} \pm 2,98 \%$ \\
\hline & Immobilized cells & & & \\
\hline (e) & pET28-QNR, pKELA & $84.5 \mathrm{mg}$ & $1: 1$ & $150 \mathrm{mg} / \mathrm{mL} \pm 2,100 \%^{\mathrm{c}}$ \\
\hline (f) & pET28-bacC, pKELA & $84.0 \mathrm{mg}$ & $1: 1$ & $24 \mathrm{mg} / \mathrm{mL} \pm 3,16 \%^{\mathrm{b}}$ \\
\hline
\end{tabular}

(a) Total amount (wet weight) of recombinant $E$. coli cells was adjusted by harvesting from a constant culture broth $(5 \mathrm{~mL}$ or $10 \mathrm{~mL})$ with varying amounts of each of the recombinant $E$. coli cells; (b) The average of three independent conversion experiments with standard deviation in shown; (c) The final concentration of 3-quinuclidinone was $15 \%(w / v)$ and the reaction time was $48 \mathrm{~h}$.

We measured the activity and stability of purified QNR and bacC [23,24] at various concentrations to check the effects on the enzymes of 2-propanol and the acetone produced. Polar organic solvents such as 2-propanol and acetone are known to inhibit enzyme activity [25]. QNR showed greater 
stability than bacC in 2-propanol-KPB ( $\mathrm{pH} 7.0)$ or acetone-KPB ( $\mathrm{pH} 7.0)$ medium (Figure 3). BacC was especially unstable in both $10 \%$ mediums. Moreover, the specific activity of bacC in 2-propanol-KPB ( $\mathrm{pH}$ 7.0) or acetone-KPB ( $\mathrm{pH}$ 7.0) medium decreased as the concentrations of 2-propanol and acetone increased, while QNR barely decreased (Figure 4). The decline in specific activity of bacC in these media was much greater than that of QNR. Thus, the data confirmed that QNR was superior to bacC for the production of $(R)-(-)$-3-quinuclidinol in 2-propanol-KPB (pH 7.0) medium. The results also suggested that it is important to keep the concentrations of 2-propanol and acetone lower than $10 \%$ during the reaction. Therefore, consecutive additions of 3 -quinuclidinone $(5 \% \mathrm{w} / \mathrm{v})$ and 2-propanol $(5 \% \mathrm{v} / \mathrm{v})$ to the reaction mixture at $8 \mathrm{~h}$ intervals suppressed the inhibitory effect of the polar organic solvent. In addition, an open reaction system without sealing was adopted to promote the vaporization of acetone from the reaction mixture. Itoh et al. reported that aeration is another effective method in asymmetric bioreduction processes using LSADH with 2-propanol to reduce the concentration of acetone [21].

Figure 3. Effect of organic solvents on enzyme stability. Residual activity is shown after incubation of designated concentration of 2-propanol or acetone and time for the purified enzymes. (a) 2-propanol on QNR; (b) acetone on QNR; (c) 2-propanol on bacC; (d) acetone on bacC. Data are the mean value of three independent measurements with standard deviation as shown.
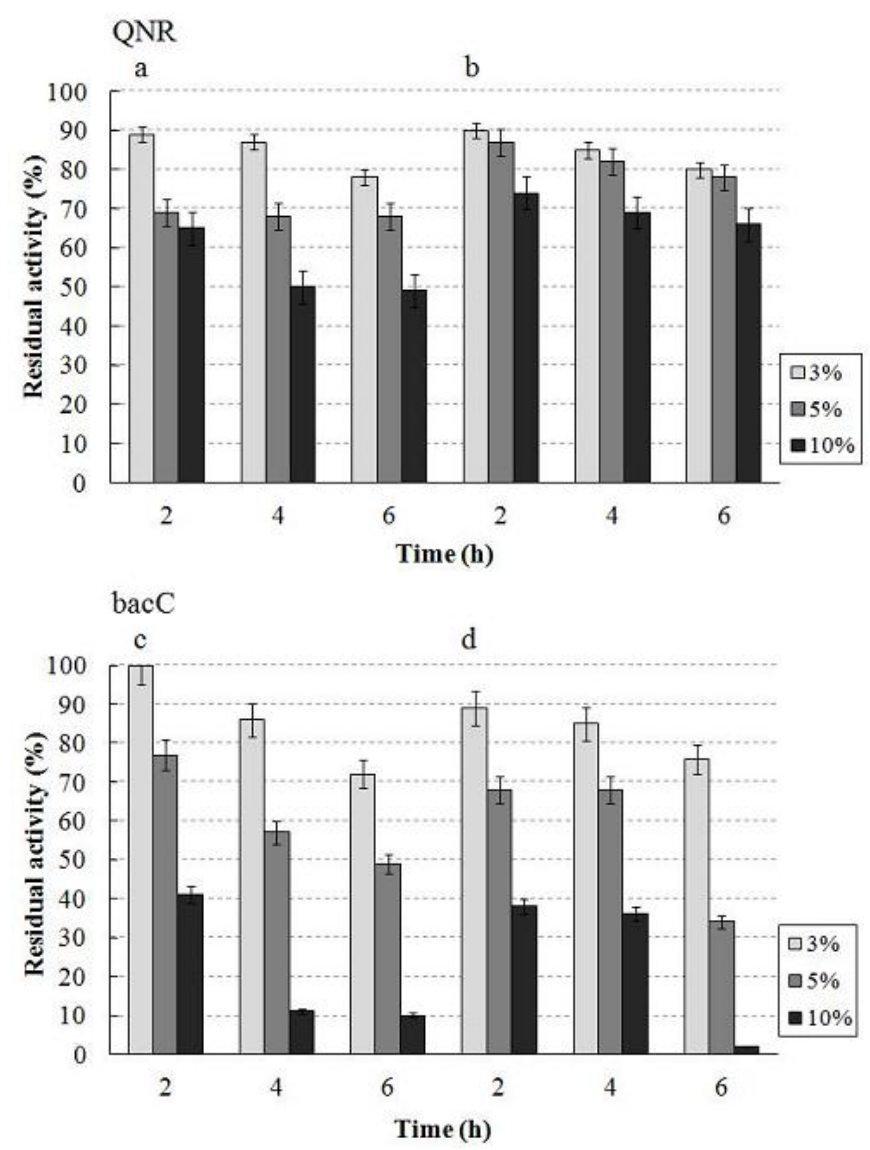
Figure 4. Effect of organic solvents on enzyme activity. Activity of QNR and bacC was measured in the presence of $0,3,5,10$ and $15 \%(v / v)$ 2-propanol/acetone in the assay mixture. Enzyme activity in the presence of 2-propanol is shown as open squares for QNR and open triangles for bacC. Activity in the presence of acetone is shown as closed squares for QNR and closed triangles for bacC. Data are the mean value of three independent measurements with standard deviation as shown.

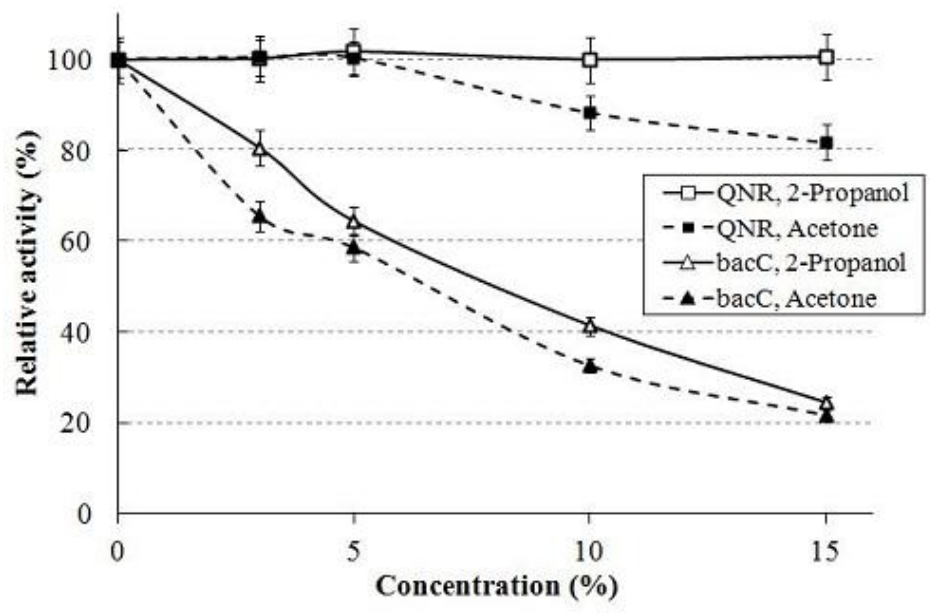

However, it was impossible to accumulate more than $10 \%$ of $(R)-(-)$-3-quinuclidinol product in the reaction mixture using intact $E$. coli cells biocatalysts even after consecutive additions of the substrate and 2-propanol (Table 2).

\subsection{Evaluation of Immobilized E. coli Biocatalyst and the Conversion Time Course}

Immobilization of recombinant $E$. coli cells often increases the operational stability of biocatalysts in the synthetic reaction. Itoh et al. reported a simple immobilization method for recombinant E. coli biocatalyst (pKELA, LSADH) using PI and GA [26], and revealed its superior operational stability for the bioreduction of 4-hydroxy-2-butanone to $(R)$-1,3-butanediol in 10\% 2-propanol-KPB $(\mathrm{pH} 7.0)$ medium [25]. We applied this method for the immobilization of E. coli/pET28-QNR, E. coli/pET28-bacC and E. coli/pKELA. Complete conversion of $15 \%(w / v)(150 \mathrm{mg}, 939 \mathrm{mM})$ 3-quinuclidinone to $(R)$-(-)-3-quinuclidinol was attained by a combination of immobilized E. coli/pET28-QNR and E. coli/pKELA, although the reaction time was extended (Figure 5 and Table 2). Low production of immobilized E. coli/pET28-bacC and E. coli/pKELA was probably due to the loss of bacC activity during the immobilization procedure. We speculated that the PI and GA polymer matrix constructed on the $E$. coli cell surface has cationic properties due to unreacted amino and imino groups of PI and hinders the access of cationic 3-quinuclidinone to the enzymes in the cells, making it possible to overcome the inhibitory effect of a high concentration of substrate. However, the lower accessibility of substrate to immobilized cells compared with intact cells prolonged the reaction time.

The production level of $(R)-(-)$-3-quinuclidinol in this study was the highest ever reported, indicating that $E$. coli biocatalysis would provide a practical method of producing important chiral compounds. 
Figure 5. Time course of the production of $(R)-(-)$-3-quinuclidinol by immobilized $E$. coli biocatalysts. The concentration of $(R)-(-)$-3-quinuclidinol is represented by a solid line and that of 3-quinuclidinone by a dashed line. Data are the mean value of three independent measurements with standard deviation as shown.

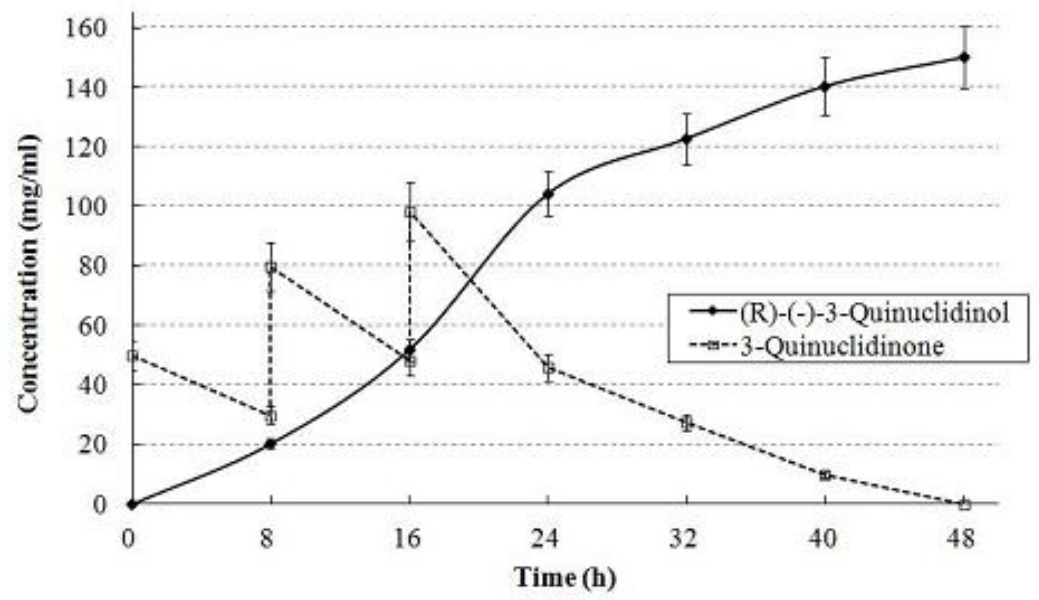

\section{Experimental Section}

\subsection{Chemicals}

3-Quinuclidinone hydrochloride was obtained from Sigma-Aldrich Chemical Co. (WI, USA). 3-Quinuclidinol and glutaraldehyde were purchased from Tokyo Chemical Industry Co., Ltd. (Tokyo, Japan), and ( $R$ )-(-)-3-quinuclidinol from Kanto Chemical Co. (Tokyo, Japan). Polyethylenimine P-70 solution $(30 \%(v / v)$ solution) was purchased from Wako Pure Chemical Industries (Osaka, Japan). All other chemicals used in this study were of analytical grade and commercially available.

\subsection{Methods}

\subsubsection{Preparation of E. coli Biocatalysts Overproducing Recombinant Enzymes}

E. coli BL21 (DE3)/pET28-QNR or E. coli BL21 (DE3)/pET28-bacC [23,24] were each grown in Luria-Bertani (LB) medium consisting of $1.0 \%(w / v)$ tryptone, $0.5 \%$ yeast extract and $0.5 \% \mathrm{NaCl}$ (pH 7.0). Pre-cultivation was carried out in the medium $(4 \mathrm{~mL})$ containing $0.05 \mathrm{mg} \mathrm{mL}^{-1}$ kanamycin sulfate in a test tube for $12 \mathrm{~h}$ at $37{ }^{\circ} \mathrm{C}$ with shaking $(180 \mathrm{rpm})$. One milliliter of the culture medium was added to fresh medium $(100 \mathrm{~mL}$ ) containing antifoam PE-H (final concentration of $0.1 \%$ ), $0.05 \mathrm{mg} \mathrm{mL}{ }^{-1}$ kanamycin sulfate and $0.4 \mathrm{mM}$ isopropyl- $\beta$-D-1-thiogalactopyranoside (IPTG) in a shaking flask at $120 \mathrm{rpm}$ and cultured at $37{ }^{\circ} \mathrm{C}$ for $24 \mathrm{~h}$. After centrifugation $(10,000 \mathrm{~g}, 5 \mathrm{~min})$, the precipitated cells from $100 \mathrm{~mL}$ of culture were washed once with $100 \mathrm{mM}$ potassium phosphate buffer (KPB) (pH 7.0) and used as a biocatalyst. E. coli BL21/pKELA was cultured according to our previous paper [20]. Cultivation of E. coli BL21(DE3)/pET28-bacC-LSADH was performed in the same manner as E. coli BL21(DE3)/pET28-QNR and E. coli BL21(DE3)/pET28-bacC. E. coli BL21(DE3)/pETDuet-QNR/pRSFDuet-LSADH were cultured with $0.05 \mathrm{mg} \mathrm{mL}^{-1}$ kanamycin sulfate, $0.1 \mathrm{mg} \mathrm{mL} \mathrm{m}^{-1}$ ampicillin and $0.4 \mathrm{mM}$ IPTG. Cultured cells $(1 \mathrm{~mL})$ were disrupted by a sonication 
device (Ultrasonic Disruptor, Tomy Seiko, Tokyo, Japan), repeated three times at $40 \mathrm{~W}$ for $10 \mathrm{~s}$ with $10 \mathrm{~s}$ intervals for cooling. After centrifugation $(10,000 \mathrm{~g}, 20 \mathrm{~min})$, the enzymatic activity in the supernatant was assayed as described below.

\subsubsection{Immobilization Procedure of E. coli Cells}

E. coli BL21 (DE3)/pET28-QNR, pET28-bacC and E. coli BL21/pKELA cells were immobilized after cultivation by the method described by Itoh et al. [25] with $3 \%(w / v)$ polyethyleneimine (PI) and $0.5 \%(w / v)$ glutaraldehyde (GA). These immobilized biocatalysts were also used for the reduction of 3-quinuclidinone.

\subsubsection{Enzyme Assay}

A spectrophotometric assay of 3-quinuclidinone reductase activity was performed by measuring the decrease in absorbance of NADH at $340 \mathrm{~nm}\left(\varepsilon=6.22 \mathrm{mM}^{-1} \mathrm{~cm}^{-1}\right)$. The assay was performed in a reaction mixture consisting of $10 \mu \mathrm{mol}$ of substrate, $0.3 \mu \mathrm{mol}$ of $\mathrm{NADH}, 50 \mu \mathrm{mol}$ of $\mathrm{KPB}(\mathrm{pH} 7.0)$ and $10 \mu \mathrm{L}$ of enzyme solution in a total volume of $1.0 \mathrm{~mL}$. LSADH activity with 2-propanol $(50 \mathrm{mM})$ was measured in the oxidative reaction. The reaction mixture consisted of $1 \mu$ mol $\mathrm{NAD}^{+}, 50 \mu \mathrm{mol}$ 2-propanol, $100 \mu \mathrm{mol} \mathrm{KPB} \mathrm{(pH} \mathrm{7.0)} \mathrm{and} 10 \mu \mathrm{L}$ enzyme solution in a total volume of $1.0 \mathrm{~mL}$. One enzyme unit was defined as the amount of enzyme that converted $1 \mu \mathrm{mol}$ of NADH or $\mathrm{NAD}^{+}$per min at $25^{\circ} \mathrm{C}$.

\subsubsection{Effect of Organic Solvent for Enzymes}

The stability of the purified enzymes $(500 \mu \mathrm{g})$ [23,24] was measured after incubation in 2-propanol/acetone and $100 \mathrm{mM} \mathrm{KPB} \mathrm{(pH} \mathrm{7.0)} \mathrm{medium} \mathrm{at} \mathrm{various} \mathrm{concentrations} \mathrm{in} \mathrm{a} \mathrm{total} \mathrm{volume} \mathrm{of}$ $1 \mathrm{~mL}$ for 2,4 and $6 \mathrm{~h}$ at $25^{\circ} \mathrm{C}$.

3.2.5. Biocatalytic Reaction to Reduce 3-Quinuclidinone to $(R)-(-)-3-$ Quinuclidinol with a Coenzyme Regenerating System

The 3-quinuclidinone conversion reaction was carried out with the coenzyme regeneration system by LSADH. The reaction mixture consisted of $200 \mathrm{mM} \mathrm{KPB} \mathrm{(pH} \mathrm{7.0),} \mathrm{5 \%} \mathrm{(w/v)} \mathrm{3-quinuclidinone,}$ $1 \mathrm{mM} \mathrm{NAD}^{+}$, various $E$. coli biocatalysts and 5\%(v/v) 2-propanol in a total volume of $1 \mathrm{~mL}$. The reaction proceeded in an unsealed $5 \mathrm{~mL}$ vial to accelerate vaporization of the acetone produced at $25{ }^{\circ} \mathrm{C}$ with shaking (2500 rpm, Taitec, Saitama, Japan) for $24 \mathrm{~h}$. Both 3-quinuclidinone and 2-propanol were added to the reaction mixture at $8 \mathrm{~h}$ intervals resulting in $10 \%$ or $15 \%$ 3-quinuclidinone/2-propanol in the reaction mixture. The E. coli biocatalysts used in Table 2 were as follows: (a) E. coli BL21 (DE3)/pET28-QNR and E. coli BL21/pKELA (total $5 \mathrm{~mL}$ or $10 \mathrm{~mL}$ culture broth), (b) E. coli BL21(DE3) pET28-bacC and E. coli BL21/pKELA (total $5 \mathrm{~mL}$ or $10 \mathrm{~mL}$ culture broth), (c) E. coli BL21 (DE3)/pETDuet-QNR/pRSFDuet-LSADH (total $5 \mathrm{~mL}$ culture broth), (d) E. coli BL21 (DE3)/pET28-bacC-LSADH) (total $5 \mathrm{~mL}$ culture broth), (e) immobilized E. coli BL21 (DE3)/pET28-QNR and E. coli BL21/pKELA (each prepared from $5 \mathrm{~mL}$ culture broth), and (f) immobilized E. coli BL21(DE3)/pET28-bacC and E. coli BL21/pKELA (each prepared from $5 \mathrm{~mL}$ 
culture broth). After the reaction, $1 \mathrm{~mL}$ of the reaction mixture was centrifuged $(18,000 \mathrm{~g}, 5 \mathrm{~min})$ and mixed with $6 \mathrm{~N} \mathrm{NaOH}(0.2 \mathrm{~mL})$, and the product was extracted twice with 1-butanol $(0.5 \mathrm{~mL})$, which contained $5 \mathrm{mM}$ 1-octanol as an internal standard. The 1-butanol layer was thoroughly dried with anhydrous $\mathrm{Na}_{2} \mathrm{SO}_{4}$ and analyzed by gas chromatography (GC) after centrifugation as described below.

\subsubsection{Product Analysis by GC}

The enantiomer of 3-quinuclidinol was analyzed by a GC system (HP 6890, Hewlett Packard, CA, USA) equipped with a chiral capillary column (CP-cyclodextrin- $\beta-236-\mathrm{N} 19,0.25 \mathrm{~mm} \times 25 \mathrm{~m}$, Varian, CA, USA) with a flame ionization detector. The GC conditions were as follows: the column temperature program ramped from $70{ }^{\circ} \mathrm{C}$ to $180{ }^{\circ} \mathrm{C}$ at $10{ }^{\circ} \mathrm{C} \mathrm{min}^{-1}$, the injection and detection temperatures were $250{ }^{\circ} \mathrm{C}$, and the He flow rate was $3.3 \mathrm{~mL} \mathrm{~min}{ }^{-1}$ with a linear velocity of $50 \mathrm{~cm} \mathrm{~s}^{-1}$ and a split ratio of 50. The retention times were $8.17 \mathrm{~min}$ for the 1-octanol internal standard, $10.94 \mathrm{~min}$ for 3-quinuclidinon, $12.69 \mathrm{~min}$ for $(S)$-(+)-3-quinuclidinol and $12.77 \mathrm{~min}$ for $(R)-(-)$-3-quinuclidinol.

\section{Conclusions}

We successfully constructed a number of $E$. coli biocatalysts, in which the QNR/bacC and LSADH genes were independently or dependently expressed, to produce optically pure $(R)-(-)$-3-quinuclidinol. By optimizing the reaction conditions including the combination of $E$. coli biocatalysts, a production level of approximately $100 \mathrm{mg} / \mathrm{mL}$ was attained with the intact $E$. coli biocatalyst process. Moreover, the combination of immobilized E. coli/pET28-QNR and E. coli/pKELA biocatalysts improved the production level to $150 \mathrm{mg} / \mathrm{mL}(939 \mathrm{mM})$ with $100 \%$ conversion.

\section{References}

1. Noyori, R.; Ohkuma, T. Asymmetric catalysis by architectural and functional molecular engineering: Practical chemo- and stereoselective hydrogenation of ketones. Angew. Chem. 2001, 40, 40-73.

2. Tokunaga, M.; Larrow, J.F.; Kakiuchi, F.; Jacobsen, E.N. Asymmetric catalysis with water: Efficient kinetic resolution of terminal epoxides by means of catalytic hydrolysis. Science 1997, 277, 936-938.

3. Jacobsen, E.N.; Kakiuchi, F.; Konsler, R.G.; Larrow, J.F.; Tokunaga, M. Enantioselective catalytic ring opening of epoxides with carboxylic acids. Tetrahedron Lett. 1997, 38, 773-776.

4. Breuer, M.; Ditrich, K.; Habicher, T.; Hauer, B.; Kesseler, M.; Stürmer, R.; Zelinski, T. Industrial methods for the production of optically active intermediates. Angew. Chem. 2004, 43, 788-824.

5. Shimizu, S.; Kataoka, M.; Kita, K. Chiral alcohol synthesis with microbial carbonyl reductases in a water-organic solvent two-phase system. Ann. N. Y. Acad. Sci. 1998, 864, 87-95.

6. Matsuyama, A.; Yamamoto, H.; Kobayashi, Y. Practical application of recombinant whole-cell biocatalysts for the manufacturing of pharmaceutical such as chiral alcohols. Org. Process Res. Dev. 2002, 6, 558-561.

7. Nakamura, K.; Yamanaka, R.; Matsuda, T.; Harada, T. Recent development in asymmetric reduction of ketones with biocatalysts. Tetrahedron Asymmetry 2003, 14, 2659-2681. 
8. Kataoka, M.; Kita, K.; Wada, M.; Yasohara, Y.; Hasegawa, J.; Shimizu, S. Novel bioreduction system for the production of chiral alcohols. Appl. Microbiol. Biotechnol. 2003, 62, 437-445.

9. Goldberg, K.; Schroer, K.; Lutz, S.; Liese, A. Biocatalytic ketone reduction-a powerful tool for the production of chiral alcohols-part I: Processes with isolated enzymes. Appl. Microbiol. Biotechnol. 2007, 76, 237-248.

10. Prat, M.; Buil, M.A.; Fernandez, M.D.; Castro, J.; Monleon, J.M.; Tort, L.; Casals, G.; Ferrer, M.; Huerta, J.M.; Espinosa, S.; et al. Discovery of novel quaternary ammonium derivatives of $(3 R)$-quinuclidinyl carbamates as potent and long acting muscarinic antagonists. Bioorg. Med. Chem. Lett. 2011, 21, 3457-3461.

11. Nomoto, F.; Hirayama, Y.; Ikunaka, M.; Inoue, T.; Otsuka, K. A practical chemoenzymatic process to access $(R)$-quinuclidin-3-ol on scale. Tetrahedron Asymmetry 2003, 14, 1871-1877.

12. Hashimoto, T.; Nakajima, K.; Ongena, G.; Yamada, Y. Two tropinone reductases with distinct stereospecificities from cultured roots of Hyoscyamus niger. Plant. Physiol. 1992, 100, 836-845.

13. Uzura, A.; Nomoto, F.; Sakoda, A.; Nishimoto, Y.; Kataoka, M.; Shimizu, S. Stereoselective synthesis of (R)-3-quinuclidinol through asymmetric reduction of 3-quinuclidinone with 3-quinuclidinone reductase of Rhodotorula rubra. Appl. Microbiol. Biotechnol. 2009, 83, $617-626$.

14. Yamamoto, H.; Ueda, M.; Pan, R.; Hamatani, T. Methods for producing optically active alcohols. U.S. Patent 2003/0143700 A1, 2003.

15. Yamamoto, H.; Mitsuhashi, K.; Kimoto, N.; Kobayashi, Y.; Esaki, N. Robust NADH-regenerator: improved alpha-haloketone-resistant formate dehydrogenase. Appl. Microbiol. Biotechnol. 2005, 67, 33-39.

16. Kataoka, M.; Yamamoto, K.; Kawabata, H.; Wada, K.; Kita, H.; Yanase, H.; Shimizu, S. Stereoselective reduction of ethyl 4-chloro-3-oxobutanoate by Eschericha coli transformant cells coexpressiong the aldehyde reductase and glucose dehydrogenase genes. Appl. Microbiol. Biotechnol. 1999, 51, 486-490.

17. Bradshaw, C.W.; Fu, H.; Shen, G.J.; Wong, C.H. A Pseudomonas sp. alcohol dehydrogenase with broad substrate specificity and unusual stereospecificity for organic synthesis. J. Org. Chem. 1992, 57, 1526-1532.

18. Stampfer, W.; Kosjek, B.; Faber, K.; Kroutil, W. Biocatalytic asymmetric hydrogen transfer employing Rhodococcus ruber DSM 44541. J. Org. Chem. 2003, 68, 402-406.

19. Inoue, K.; Makino, Y.; Itoh, N. Production of $(R)$-chiral alcohols by a hydrogen-transfer bioreduction with NADH-dependent Leifsonia alcohol dehydrogenase (LSADH). Tetrahedron Asymmetry 2005, 16, 2539-2549.

20. Inoue, K.; Makino, Y.; Dairi, T.; Itoh, N. Gene cloning and expression of Leifsonia alcohol dehydrogenase (LSADH) involved in asymmetric hydrogen-transfer bioreduction to produce (R)-form chiral alcohols. Biosci. Biotechnol. Biochem. 2006, 70, 418-426.

21. Itoh, N.; Isotani, K.; Nakamura, M.; Inoue, K.; Isogai, Y.; Makino, Y. Efficient synthesis of optically pure alcohols by asymmetric hydrogen-transfer biocatalysis: application of engineered enzymes in a 2-propanol-water medium. Appl. Microbiol. Biotechnol. 2012, 93, 1075-1085. 
22. Jakoblinnert, A.; Madenov, R.; Paul, A.; Sibilla, F.; Schwaneberg, U.; Ansorqe-Schumacher, M.B.; de Maria, P.D. Asymmetric reduction of ketones with recombinant E. coli whole cells in neat substrates. Chem. Commun. 2011, 47, 12230-12232.

23. Itoh, N. Quinuclidinone reductase and method for producing optically active 3-quinuclidinol. Jpn. Patent JP2010-051207 A, 2010.

24. Itoh, N. Quinuclidinone reductase and method for producing optically active 3-quinuclidinol. Jpn. Patent JP2011-147349 A, 2011.

25. Itoh, N.; Nakamura, M.; Inoue, K.; Makino, Y. Continuous production of chiral 1,3-butanediol using immobilized biocatalysts in a packed bed reactor: Promising biocatalysis method with an asymmetric hydrogen-transfer bioreduction. Appl. Microbiol. Biotechnol. 2007, 75, 1249-1256.

26. Bahulekar, R.; Ayyangar, N.R.; Ponrathnam, S. Polyethyleneimine in immobilization of biocatalysts. Enzym. Microb. Technol. 1991, 13, 858-868.

(C) 2012 by the authors; licensee MDPI, Basel, Switzerland. This article is an open access article distributed under the terms and conditions of the Creative Commons Attribution license (http://creativecommons.org/licenses/by/3.0/). 